\title{
IN DEFENCE OF THE NORTH AMERICAN ROLLING CHARGE
}

\section{Sarah Lowrie \& Paul Todd $^{* *}$}

In Barlow Clowes v. Vaughan, ${ }^{1}$ the Court of Appeal reluctantly accepted that the rule in Clayton' $s$ case ${ }^{2}$ remained generally applicable to competing claims in equity, to mixed funds in running bank accounts. This first-in first-out rule operates rather like a bus queue, attributing successive payments out of an account to the earliest payment in. The effect of this is that if money is dissipated from the account, Clayton's case benefits later payments in, whereas if money from the account is committed to an investment which increases in value, the rule benefits earlier payments in. In both cases, a great deal can turn capriciously on the chance order of payments. It is perhaps not surprising, therefore, that neither in Barlow Clowes, nor indeed in any other case, has the rule been wholeheartedly embraced. Indeed, in Barlow Clowes itself, there was a strong entreaty to the House of Lords to reconsider the rule. ${ }^{3}$

The purpose of this article is to advance suggestions as to how the law should rationally develop, if ever the House should have this opportunity. It will be suggested that the North American Rolling Charge, which has not generally

\footnotetext{
" University College, Swansea.

** Cardiff Law School.

${ }^{1}$ [1992] 4 All E.R. 22, [1992] B.C.L.C. 910.

${ }^{2}$ (1816) 1 Mer. 572, [1814-23] All E.R. Rep.1, 35 E.R. 781.
}

${ }^{3}$ Supra.n. 1 per Woolf L.J. at 39a: " ...short of the House of Lords, it is settled law that the rule in Clayton's Case can be applied to determine the extent to which, as between each other, equally innocent claimants are entitled in equity to moneys which have been paid into a bank account and then subject to the movements within that account." This is an unenthusiastic statement of Woolf L.J.'s view of the existing law. Nor is Leggatt L.J.'s acceptance of the application of Clayton's case overwhelming at 43b: "During the 175 years since the rule in Clayton's Case was devised neither its acclaim nor its application has been universal." 


\section{DENNING LAW JOURNAL}

been greeted with enthusiasm by courts in the United Kingdom, ${ }^{4}$ should have a significant role to play. Even in the absence of reconsideration of Clayton's case by the House, the extent to which, if at all, present authorities constrain such suggestions, will be questioned.

For the purposes of this discussion, it will be assumed that the equities between each claim are equal. ${ }^{5}$ The existence of an initial fiduciary relationship, allowing tracing in equity, will be assumed. ${ }^{6}$ There seems little doubt that courts in the United Kingdom lean towards a pari passu approach to distribution, ${ }^{7}$ and there are circumstances where this is the fairest approach. For example, suppose a trustee pays $£ 100$ of Alpha's money and $£ 200$ of Beta's into a mixed fund and then dissipates $£ 150$, leaving $£ 150$ in the account. It is

${ }^{4}$ However, in Barlow Clowes, Leggatt L.J. observed at supra.n.1 at 44c: "As between beneficiaries to whom money in an account belongs, they should share loss in proportion to their interest in the account immediately before each withdrawal. The fairness of that course is obvious. It is exemplified by the judgment of the court in Re Ontario Securities Commission v. Greymac Credit Corp.(1986) 55 O.R. (2d) 673. But if, as here, that calculation is too difficult or expensive, the beneficiaries should in my judgment share rateably." This is a clear endorsement of the rolling charge in any case where calculation is not too difficult or expensive.

${ }^{5}$ In other words, excluding the situation in cases such as Re Hallet's Estate (1880) 13 Ch.D. 696, where the mixing was done by a trustee. Re Diplock [1949] Ch. 465 is authority that Re Hallett's Estate does not apply where funds are mixed with those of a volunteer. In Westdeutsche Landesbank Girozentrale v. Islington L.B.C. [1996] 2 All E.R. 961 at 987, Lord Browne-Wilkinson's reductio ad absurdum involving $\mathrm{T}, \mathrm{R} 1$ and $\mathrm{R} 2$, depends on Re Hallett's Estate applying to R2, who is a volunteer, but this in turn depends on the bank's argument being correct, a proposition which all their Lordships rejected, although a minority would have held in the bank's favour on another issue.

${ }^{\circ}$ A requirement restated by Lord Browne-Wilkinson in Westdeutsche ibid. at $996 \mathrm{e}$.

${ }^{7}$ The House of Lords had to strain to reach this result in Sinclair v. Brougham [1914] A.C. 398 where the shareholders and depositors could be regarded as equally innocent or equally guilty: e.g. at 451-452 per Lord Sumner, who observed that although few if any suspected that the banking business was ultra vires, all had notice of the rules, and so ought to have known. Either way, the equities between them were equal. See also Barlow Clowes supra.n.1 and Re Diplock's Estate supra.n.5, except for the claims involving Dr.Barnardo's Homes and the National Institute for the Deaf, where Claylon's case was applied: see infra.n.17 \& text also supra.n.5 at 551-554, and in the case of the National Institute for the Deaf [1948] 2 All E.R. 429. Though Sinclair v. Brougham was overruled in Westdeutsche supra.n. 5 at $996 \mathrm{f}$, this was on the grounds that equitable tracing ought not to have been possible at all, rather than on the principles of pari passu distribution. 


\section{IN DEFENCE OF THE NORTH AMERICAN ROLLING CHARGE}

difficult to argue that any result is fairer than pari passu distribution, giving

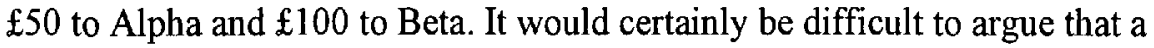
fairer solution would depend on the order in which the moneys were deposited. By contrast, an application of the rule in Clayton's case would benefit the later depositor: if Alpha's money were deposited first, Alpha would obtain nothing, whereas if Beta's money were deposited first, Beta would obtain only $£ 50$ but Alpha would lose nothing. So here, pari passu clearly leads to a fairer distribution than Clayton's case.

However, it by no means follows that pari passu necessarily achieves a fairer result. Suppose that the above example is varied, in that for some time prior to paying Beta's $£ 200$ into the mixed account, the trustee has been using the account for depositing payments from Alpha, and that a total of $£ 400$ of Alpha's has been paid into the account at some time. However, over the same period the trustee has dissipated some of the money, so that only $£ 100$ remains. Then Beta's $£ 200$ is paid in, and as before, a further $£ 150$ dissipated, leaving $\mathfrak{1 5 0}$ in the account. In this case, a pari passu distribution would give the Alpha the benefit of the entirety of the $£ 400$, implying that he has contributed twice as much to the fund as Beta. Thus, Alpha would get $£ 100$ and Beta only $\mathfrak{E 5 0}$. This seems unfair on Beta, who is now adversely affected by payments into and out of the account prior to the mixing. A similar point is made by Lord Justice Dillon in Barlow Clowes, where contrasting Clayton's case with pari passu, he observed that pari passu operates against later investors where money has been dissipated from the account:

"For my part, so far as fairness is concerned, I have difficulty in seeing the fairness to a later investor ... of holding that all those moneys must be shared pari passu by all investors early or late if there was no common investment fund ... If the application of Clayton's case is unfair to early investors pari passu distribution among all seems unfair to late investors."

If, on the other hand, the $£ 300$ which had been withdrawn prior to Beta's deposit, had been committed to an investment now worth $£ 600$, Beta obtains a share in the investment on pari passu principles, even though there is no meaningful sense in which his or her money was used. Where money is profitably invested, rather than dissipated, pari passu tends to benefit the later

\footnotetext{
${ }^{8}$ Supra.n.1 at 32c.
} 


\section{DENNING LAW JOURNAL}

investors.

By contrast, an application of the rule in Clayton's case would benefit Beta in the first case, where as before, Alpha would obtain nothing, and benefit Alpha in the second. Here, Alpha would get the entirety of the investment, and Beta would only obtain the benefit of the money remaining in the account. These solutions are not obviously any fairer than pari passu, since in neither case does Alpha obtain any benefit from what remains in the account, although $£ 100$ remained prior to Beta's investment. So here, neither pari passu nor Clayton's case leads to a fair solution.

A third approach, sometimes referred to as the North American Rolling Charge, has been met with little enthusiasm by the courts, ${ }^{9}$ but could if adopted resolve both the above problems of the pari passu approach, without leading to any of the unfairness of Clayton's case. Here the case in principle for the North American Rolling Charge will be examined along with its limitations, and the authorities for and against its adoption.

\section{THE WORKING OF THE NORTH AMERICAN ROLLING CHARGE}

The North American Rolling Charge was described by Lord Justice Woolf in Barlow Clowes as follows:

"This solution involves treating credits to a bank account made at different times and from different sources as a blend or cocktail with the result that when a withdrawal is made from the account it is treated as a withdrawal in the same proportions as the different interests in the account (here of the investors) bear to each other at the moment before the withdrawal is made." 10

${ }^{9}$ E.g. in Barlow Clowes supra.n. 1 at $28 \mathrm{a}-\mathrm{b}$, Dillon L.J.(at $33 \mathrm{~d}$ ) said: "The complexities of this method would, however, in a case where there are as many depositors as in the present case and even with the benefits of modern computer technology be so great, and the cost would be so high, that no one has sought to urge the court to adopt it, and I would reject it as impracticable in the present case." Woolf L.J. took a similar view at $35 \mathrm{j}$, but also observed that it is the fairest method in some situations. Dillon L.J. thought it had in any case been ruled out by authority, having been decisively rejected in Re Diplock; Leggatt L.J. took a slightly more favourable view of the principle.

${ }^{10}$ Supra.n. 1 at $35 \mathrm{~h}$. A functionally similar description can also be found in Dillon L.J.'s judgment at $27 \mathrm{~h}-28 \mathrm{~b}$. 
Applied to the first example above, the North American rolling charge will give exactly the same result as pari passu. In the second example, where the money is dissipated before Beta's money is paid in, it gives the same result as in the first example, because all the dissipations are regarded as Alpha's, surely the fairest solution? Where instead of being dissipated, the money is committed to the investment which has doubled in value, the result is still the same regarding the bank account, but Alpha also gets the benefit of the totality of the investment. This also seems fairest, as Beta has not, in any meaningful sense, contributed to the investment. It is also a fairer solution, in this situation, than Clayton's case, because Alpha's money was not exhausted by the purchase of the investment, and it is therefore reasonable that he retains an interest in the money remaining in the account.

\section{THE CASE IN PRINCIPLE FOR THE NORTH AMERICAN ROLLING CHARGE}

In spite of the reluctance of the courts in the United Kingdom to embrace the North American Rolling Charge, it is contended that it has a number of advantages, and will normally be the fairest method of distribution. One advantage is that prior property rights are never disturbed by later transactions. Later payments in do not diminish existing interests in the remaining fund, nor do later payments in obtain the advantage of earlier investments. There is also no distortion of existing beneficial interests in any property purchased from proceeds from the fund.

Another justification in principle is that once moneys have lost their identity by being mixed into an account, the proportions attributable to each contributor can be calculated. These proportions should not change if the account is later diminished, or split into more than one account. This was of the view taken in Scott on Trusts, in a passage quoted in Re Ontario Securities Commission v. Greymac Credit Corporation:

"... The claimant has an equitable lien upon the mingled fund, and when a part of the fund is withdrawn he has an equitable lien on the part withdrawn and on the part which remains. If the part which is withdrawn is dissipated so that it can no longer be traced; the claimant still has his equitable lien on the part which remains. So also, as we shall see, if the part which is withdrawn is preserved and the part which remains is subsequently dissipated, the 


\section{DENNING LAW JOURNAL}

claimant has an equitable lien upon the part which is withdrawn. It is impossible and unnecessary to determine whether the claimant's money is included in the part withdrawn or in the part which remains. It is impossible to determine which part is the claimant's money, since his money has been so commingled as to lose its identity. It is unnecessary to determine which part is the claimant's money, since he is entitled to an equitable lien upon both parts. ... It is true that where the part of the fund which is withdrawn is dissipated and the balance is preserved, the claimant is certainly entitled to payment of his claim out of the balance. The reason is that his lien on the entire fund undoubtedly includes the balance of the fund after a part has been withdrawn.

... The only tenable principle is that the claimant can enforce a lien upon any part or the product of any part of the mingled fund." 11

In Re Ontario Securities, the Court of Appeal for Ontario adopted the North American Rolling Charge in a claim involving competing interests in a fund. In essence, this case involved the account of a trustee, (Greymac Credit Corporation)[G.C.C.] in which was deposited funds entrusted to G.C.C. for two beneficiaries. One beneficiary was a trio of companies, Greymac Trust Company [G.T.C.], Crown Trust Company [C.T.C.] and Seaway Trust Company ["the companies"], and the other was Chorny Mortgage Investor Participants ["the participants"]. The moneys of these two separate beneficiaries were mixed by the trustee into his account at G.T.C.

The money first mixed into the G.T.C. account belonged to the companies, and only later did the trustee mix in money belonging to the participants. There was also some money of the trustee's own, but on the reasoning in Re Hallett's Estate, ${ }^{12}$ at the time when the participants' money was placed in the account, all the other money in it belonged to the companies. Prior to this, however, there had been other payments in of companies' money, and withdrawals, so that more money belonging to the companies had been paid into the account than remained at this time.

11 Scott on Trusts (3rd.ed., Little Brown, 1967) at pp.3620, $3623 \& 3624$, quoted in Re Ontario Securities Commission v. Greymac Credit Corporation (1986) 55 O.R. (2d.) 673 at 682a-b (Ont.C.A.).

12 Supra.n.5 (because all money withdrawn was therefore presumed to belong to the trustee). 


\section{IN DEFENCE OF THE NORTH AMERICAN ROLLING CHARGE}

The first withdrawal made by the trustee was of $\$ 4,000,000$, which was placed into another account (at one of the beneficiary "companies", C.T.C.). This money remained intact. Later, the trustee made several subsequent withdrawals from the G.T.C. account, the proceeds of which were dissipated. This left just under $\$ 400,000$ in the original mixed account.

Both beneficiaries, "the companies" and "the participants," each asserted proprietary claims against these two amounts. What the court had to decide was how these funds should be divided between the claimants, and upon what principle this should be done.

At first instance, Parker A.C.J.H.C. held that the loss must at first be deemed to be against the trustee's interest, on Re Hallett 's Estate reasoning. ${ }^{13}$ This aspect of the decision was not part of the appeal heard in the Supreme Court. Then, Mr.Justice Parker decided that the funds should be divided according to the respective contributions made by, or on behalf the two beneficiaries. This meant that approximately 85 per cent of each fund belonged to the companies and 15 per cent to the participants.

The companies appealed from the original decision, claiming essentially that they were entitled to the entirety of the larger sum (they conceded that they were not entitled to any of the smaller sum, but the total on this basis still worked out better for them). They claimed that the judge was mistaken in basing the distribution on pro rata principles, when instead, the rule in Clayton's case should have been applied. On the "first in, first out" reasoning, the first moneys paid into the trustee's account at G.T.C. were those of the companies, and subsequent deposits were those of the participants. Thus, when the trustee removed the money from the G.T.C. Trust account, and deposited it with C.T.C. (i.e. the large undissipated sum), the money concerned must necessarily have been that of the companies. At first instance, Mr. Justice was critical of Clayton's case, but the appellants challenged his decision basing their action on both principle and authority.

The companies advanced an alternative pari passu argument. Their argument was that the time from which the calculation of shares should start should be earlier, since more money had originally been deposited by the companies into the G.T.C. account, and that this also should be taken into account in any distribution.

The participants insisted that the view of Mr.Justice Parker was correct, but also advanced alternative arguments, with which the Ontario Court of Appeal

${ }^{13} 51$ O.R. (2d) 212. 


\section{DENNING LAW JOURNAL}

was wholly unimpressed, that Clayton's case only applies to dissipations from a mixed fund, not to investments made with money from it, and therefore that the rule applied only after the removal of the $\$ 4$ million to the C.T.C. account. ${ }^{14}$

The Court of Appeal adopted Mr.Justice Parker's approach, but rejecting the companies' argument that the starting point should be earlier, since at the earlier time there was no participants' money in the G.T.C. account, and that therefore the participants should not be contaminated by anything that had occurred at this time:

"The appellants submit that if the equality, that is, pro rata sharing, approach is to be followed, then to do justice more money furnished by the companies to the trustee than the ... balance of December 15, 1982 [when the participants' money was paid in] should be taken into account. ... If the proper approach is equality, then, it is submitted, this fact [earlier payments in by the companies] should be taken into account. ... Quite apart from the fact that the question of whether any part of the original [money in the account prior to December 15, 1982] ... was returned to the companies in some form was not inquired into, I do not think that this particular argument of the appellants is of assistance to them. We are concerned with the resolution of competing proprietary, not personal, claims. At the time of the mingling of the trust funds the companies had $\$ 4,683,000$ in the account. Regardless of how much they had earlier in the account, they cannot say that they had a proprietary interest in any more than the amount in the account to their credit on and after December 15, 1982., 15

Although the words "North American Rolling Charge" do not appear in the judgments, the case is clearly based upon the concept, and justifies it.

To summarise, the main argument in favour of the North American Rolling Charge is that it does not allow later dealings to affect already-established property rights. However, in Re Ontario Securities, Mr.Justice Parker accepted that there might be practical difficulties, in certain circumstances, in adopting the rolling charge, in which case he made no observations on the appropriate

${ }^{14}$ Supra.n. 11 at $681 \mathrm{~h}-682 \mathrm{a}$.

${ }^{15} \mathrm{Ibid}$. at $687 \mathrm{f}-688 \mathrm{c}$. 


\section{IN DEFENCE OF THE NORTH AMERICAN ROLLING CHARGE}

method of apportionment:

"I express no opinion on the power of the court to make a disposition on some other basis where it is not possible to determine what proportion the mixed funds bear each to the other."

The view of the Court of Appeal was that it would not apply Clayton's case at all to the resolution of problems connected with competing beneficial entitlements to a mingled trust fund, where there have been withdrawals from the fund.

\section{PRACTICAL OBSERVATIONS ON THE NORTH AMERICAN ROLLING CHARGE}

There are two further points to note about the North American Rolling Charge, both of which may explain why it has rarely been argued in the United Kingdom. First, it will not often be the best option of either party to any dispute. In a case such as Barlow Clowes, for example, a pari passu distribution would have produced a more favourable outcome than the North American Rolling Charge for the early investors. By contrast, the later investors were better off arguing Clayton's case than the North American Rolling Charge. This will generally be the position where money is dissipated, whereas the North American Rolling Charge tends towards an intermediate result. The opposite position obtains where a valuable investment is purchased, where pari passu benefits later investors, and Clayton's case earlier, and again the North American Rolling Charge adopts a middle position.

For example, suppose a trustee places $£ 10$ belonging in equity to Paul into an account, then a further $£ 10$ belonging to Michael, then dissipates $£ 10$, then places in the account a further $£ 20$ belonging to Karen. There is therefore, at this stage, $\mathfrak{f 3 0}$ in the account, whereas a total of $£ 40$ has been paid in. Pari pass $u$ therefore gives everybody three-quarters of their contribution, i.e. $£ 7.50$ to each of Paul and Michael, and $£ 15$ for Karen. It is worth observing that Karen has lost out because of the withdrawal of $£ 10$, a transaction which

${ }^{16}$ Quoted in ibid. at 679g. 


\section{DENNING LAW JOURNAL}

occurred before she had paid anything in, and in which she was therefore in no sense involved.

Clayton's case attributes the whole of the $\mathfrak{1 1 0}$ dissipated to the first payment in, so that Paul ends up with nothing in the account, and Michael and Karen recover the entirety of their contributions. This seems very unfair on Paul, whose equity would seem to be in no way distinguishable from Michael's.

The North American Rolling Charge recognises that Paul's and Michael's equities are equal, and apportions the $£ 10$ dissipated equally to the two of them. Karen is unaffected by the $\mathfrak{f} 10$ withdrawal, and the distribution is therefore $\mathfrak{E} 5$ to each of Paul and Michael, and $£ 20$ to Karen.

In this case, nobody has a clear advantage in claiming under the North American Rolling Charge, although Karen obtains the same by this method as she would under Clayton's case. Paul obtains more under pari passu than under the North American Rolling Charge, whereas Michael obtains more under Clayton's case.

If instead of being dissipated, the $\mathfrak{f} 10$ is spent on a first edition now worth $£ 50$, the total value of the fund plus the investment is now $£ 80$, or twice the contribution of each of the parties. Pari passu therefore gives each twice their contribution, i.e. $£ 20$ for Paul and Michael, and $£ 40$ for Karen. This time, Karen has gained the benefit of an investment to which she cannot have made any meaningful contribution.

Clayton's case attributes the entirety of the investment to Paul, who can therefore claim its value of $\mathfrak{E} 50$, and the others obtain exactly their payments in, i.e. $£ 10$ for Michael and $£ 20$ for Karen. Yet Paul's and Michael's equities would again seem to be equal.

The North American Rolling Charge recognises this by attributing the investment equally to Paul and Michael, giving each $£ 25$ in the investment plus the $£ 5$ each has remaining in the account (i.e. a total value of $£ 30$ each). Karen obtains her payment in, of $£ 20$, which is fair, because she has not contributed to the investment.

Once again, it is in neither Paul nor Karen's interests to claim the North American Rolling Charge method of distribution. Paul will attempt to argue Clayton's case and Karen pari passu. However, it should not be assumed that the North American Rolling Charge will never be the preferred method of distribution, since clearly Michael should claim it here. Moreover, in the original example, where the investment was purchased with Alpha's money, the North American Rolling Charge would have been his choice method of distribution, as indeed it also was for the participators in the Re Ontario 


\section{IN DEFENCE OF THE NORTH AMERICAN ROLLING CHARGE}

Securities case. In general, however, it will rarely be the preferred method of distribution for any of the parties, which may explain why it has never been argued in a court in the United Kingdom.

The second observation to make on the North American Rolling Charge is that it will never be the cheapest method of distribution. To operate a pari passu distribution, the only information that is required is the total of payments into the mixed account, and the total remaining. There is no need to trace the individual movements within the account, so that where there are a large number of transactions, as in Sinclair v. Brougham or Barlow Clowes, pari passu will obviously be the easiest method. Where money from an account is dissipated, the rule in Clayton's case removes from the account all earlier deposits, so that it is not necessary to know about them, or about the total of payments into the mixed account. There are some situations, therefore, where pari passu is more difficult to operate than Clayton's case. Suppose, for example, that a trustee has been paying money from various trust funds through a mixed account over a long period. On a pari passu distribution, assuming the fund has remained in credit, every contributor whose account is in credit will have some claim on the fund. This would require all the account's dealings over the entire period to be examined, and it is easy to conceive of circumstances where this is impracticable. This is a possible justification for applying Clayton's case to running bank accounts, ${ }^{17}$ which has the effect of depriving all but the latest depositors of any interest. Clayton's case operates capriciously, however, and is difficult to justify except to resolve the impracticality. ${ }^{18}$

Where on the other hand, payments from a mixed account are committed to a profitable investment, Clayton's case can also sometimes operate more simply than pari passu, because any moneys paid in after the investment was made will be discounted. Again, therefore, there is no need to enquire into these, or into the total of payments into the account.

To operate the North American Rolling Charge, unless the account has at some stage become overdrawn, it is necessary to examine the whole history of

${ }^{17}$ E.g. in Re Diplock in respect of the Dr.Barnardo and the National Institute for the Deaf accounts: supra.n.7.

18 The courts appear to adopt Clayton's case only as a last resort, and have shown reluctance to extend its operation beyond running bank accounts; e.g., Borlow Clowes supra.n. 1 at esp. 28c-e per Dillon L.J.; Re Diplock's Estate supra.n.5 (except for the running bank accounts referred to supra.n.7). 


\section{DENNING LAW JOURNAL}

the account, the amount of every payment in and out, and the order of payments. This is always likely to be at least as difficult as either of the alternative methods of distribution, and will often be more difficult.

\section{CASES IN PRINCIPLE WHERE THE APPLICATION OF THE NORTH AMERICAN ROLLING CHARGE WOULD NOT BE APPROPRIATE}

\section{Although the North American Rolling Charge reaches the fairest result in} usual circumstances, it depends on the intention of the parties being that later payments should not affect earlier established rights. However, where the intention is to share a collective fund, the parties will intend that later payments should affect earlier established rights, and pari passu distribution will accord with this intention. This is a possible justification for the result in Barlow Clowes, ${ }^{19}$ and will often be a reasonable inference in unincorporated association cases. ${ }^{20}$ The intention of the parties was also regarded as justification for departure from the North American Rolling Charge in Ontario itself:

"Another exception, an obvious and necessary one, which might often overlap with the kind of case just referred to, would be the case where the court finds that the claimants have, either expressly or by implication, agreed among themselves to a distribution based otherwise than on a pro rata division following equitable tracing of contributions." 21

${ }^{19}$ Indeed, this was expressly the basis of Dillon and Leggatt L.JJ.'s reasoning in the case. Woolf L.J.'s reasoning was based more generally on the intention of the parties, but again depends on the notion of the parties contributing to a common misfortune, so that they would not want to 'subject what was left of the pool to the vagaries of chance which would follow from the first in first out principle' supra.n.1 at $4 \mathrm{le}-\mathrm{h}$. The reasoning was directed primarily to a refusal to apply Clayton's case, but it would have been equally apposite in an argument against the application of a North American Rolling Charge.

${ }^{20}$ It might aiso justify the pari passu distribution in Sinclair v. Brougham supra.n.7, at least as far as the building society investments were concerned. The usual presumption for unincorporated associations is equality, rather than pari passu distribution, Re Hobourn Aero Components Air Raid Distress Fund [1946] Ch.86, affirmed on other grounds [1946] Ch.194, which adopted pari passu, being an exceptional case.

${ }^{21}$ Supra.n. 11 at $690 \mathrm{e}$. 


\section{IN DEFENCE OF THE NORTH AMERICAN ROLLING CHARGE}

Another departure from the North American Rolling Charge (or indeed, any of the approaches considered so far) was made by Mr.Justice Millett in El Ajou v. Dollar Land Holdings p.l.c. ${ }^{22}$ Here, while it was clear that the plaintiff was the principal victim of a complicated fraud, and that the defendant's only money appeared to have come from the proceeds of the fraud, the records of transactions had not been fastidiously kept, the fraudsters presumably being motivated to hide their fraud, and frustrate tracing claims. Clearly, it would have been impossible to apply either Clayton's case or the North American Rolling Charge, given this paucity of evidence. Possibly, had Mr.Justice Millett had the benefit of the Barlow Clowes decision, which had not at that time been reported, ${ }^{23}$ he would have adopted a pari passu approach. Instead, however, he matched large cheques from the plaintiff into a running account with similarsized cheques out of it, in order to establish that the defendant had received money belonging in equity to the plaintiff. ${ }^{24}$ This might be justified if the similarity between the cheques in and out gave rise to the inference that the plaintiff's money was never truly mixed into the running account. ${ }^{25}$

Although Mr.Justice Millett held that the money could be traced into the hands of the defendant, he also held that the defendant did not have the requisite knowledge for a knowing receipt claim. His decision in this respect was reversed by the Court of Appeal, ${ }^{26}$ who sent it back on quantum. In El Ajou v. Dollar Land Holdings p.l.c. (No. 2), Mr.Justice Robert Walker took the view that where there are no competing proprietary claims, and all that is desired is to trace the plaintiff's property into the hands of the defendant for the purposes of establishing a knowing receipt claim, it is unnecessary to apportion

${ }^{22}[1993] 3$ All E.R. 717

${ }^{23}$ As Robert Walker J. observed in El Ajou v. Dollar Land Holdings p.l.c. (No. 2) [1995] 2 All E.R. 213 at $222 f$.

${ }^{24}$ E.g. supra.n. 22 at $724 \mathrm{j}-725$ e, although the matching was not exact. The claim was in knowing receipt, not tracing: see further infra.n.26 \& text.

${ }^{25}$ Although Millett $\mathbf{J}$, appears to have proceeded on the assumption that it was: supra.n.22 at $724 \mathrm{~h}$. But the suggested inference is reasonable, whereas if the money had been truly mixed, then it is difficult, on any known principle, to justify Millett J.'s method of calculating the amount the defendant had received of money belonging to the plaintiff. 


\section{DENNING LAW JOURNAL}

competing claims at all. ${ }^{27}$ His desired result appears to have been to ensure that the defendant obtained no benefit from the fraud, although there were other claims, apart from the plaintiff's, when it looked unlikely that any of the other claimants would sue. However, this distinction between apportioning for proprietary, but not for personal claims, can lead to difficulties in practice. ${ }^{28}$ Suppose, for example, any of the others, contrary to expectation, had sued. Either the defendant would be liable for more than he had received, or it would be necessary to resolve the problem on an arbitrary first come first served basis. There is also a principled objection to Mr.Justice Robert Walker's approach, which is that although the defendant had apparently received a large amount of money from the proceeds of fraud, not all of it was from a fraud on the plaintiff. If fraud victims, for whatever reason, decide not to sue, then it is an inevitable consequence that the fraudster will keep some of his ill-gotten gains. That is simply the nature of litigation, and is not a consequence that can be avoided. It is therefore contended that an apportionment should have taken place in El Ajou (No. 2), on the principles discussed in this article.

In this section, however, two situations where the North American Rolling Charge would be inappropriate have been considered, namely where the investment is into a common fund, as in Barlow Clowes, and where the money is never truly mixed, which is a possible explanation of Mr.Justice Millett's approach in $E l A j o u$. In any case where justification from the North American Rolling Charge can be made out in principle, the justification is in favour of pari passu, or an entirely different tracing principle, such as that adopted in $E l$ Ajou, rather than Clayton's case. The only justification for adopting the rule in Clayton's case is one of administrative workability, especially in the case of a running bank account, where both pari passu and the North American Rolling Charge would be difficult to operate, in the first case because it is difficult to apportion where there have been many payments into and out of a fund over many years, and in the second case because for the same reason, it is difficult to apportion payments out.

Therefore administrative workability arguments are considered next.

\section{${ }^{27}$ Supra.n.23.}

${ }^{28}$ It is not sufficient, as Robert Walker J. does, ibid. at $223 \mathrm{c}$, to justify the result on the basis that tracing depends on equity's capacity to impose a charge, rather than its actual imposition, because if the other parties had sued it would have been necessary actually to determine the extent of each charge. 


\section{IN DEFENCE OF THE NORTH AMERICAN ROLLING CHARGE}

\section{ADMINISTRATIVE WORKABILITY ARGUMENTS}

It is easy to see how, in the case of a long-term active running account, from which money is frequently dispersed, Clayton's case is the easiest test to administer, because the earliest payments in are simply removed from the equation. It might be thought that in the usual case, the North American Rolling Charge will also be easier to administer than pari passu (at least where there are dissipations) because each withdrawal reduces the number of claimants, so the earliest depositors will be ruled out just as they are with Clayton's case. This is only actually going to be the case, however, if the earlier dissipations are such as to reduce some claims to zero, but in principle, both pari passu and the North American Rolling Charge require the entire history of the bank account to be known.

However, pari passu is itself sometimes justified on the grounds that it is easier than either of the other two methods to administer, ${ }^{29}$ and indeed, there are exceptional cases where this will be true. In Barlow Clowes and El Ajou, for example, the total investment, and the total remaining in fund, were both known, but in $E l A j o u$, inadequate records had been kept, and there was an inadequate trail, which would have made either of the other methods impossible. In Barlow Clowes there were a large number of transactions, which would have made either of the other methods difficult, but not impossible. ${ }^{30} \mathrm{It}$ is suggested, however, that neither of these cases represents a good ground for departing from the North American Rolling Charge.

In a case such as $E l A j o u$, it would clearly be inappropriate, on public policy grounds, to develop a rule which encouraged fraudsters to keep inadequate (or no) records, or allowed them to benefit from so doing. It was pretty clear in $E l$ Ajou that the only money the Canadians had was derived from the frauds considered in the case, so to distribute pari passu would have been to deprive the fraudsters of any of their gain, whereas this would not have been the case had every individual claimant been required to prove his or her entitlement on a

${ }^{29}$ E.g. Report of the Review Committee on Insolvency Law and Practice (Cork Report, Cmnd. 8558, H.M.S.O., 1982) paras.1076-1080; Barlow Clowes, where cost was one of the reasons why none of the parties argued for a North American Rolling Charge distribution: supra.n. 1 at $28 \mathrm{~b}$ per Dillon L.J., at $35 \mathrm{j}$ per Woolf L.J.

${ }^{30}$ Per Woolf L.J. supra.n. 1 at 35 j (on the North American Rolling Charge). Pari passu would also have been easiest to apply in Hobourn Aero supra.n. 20 where like Barlow Clowes the total investment and total fund remaining were both known. 


\section{DENNING LAW JOURNAL}

rolling charge basis. However, this problem is easily resolved by evidence presumptions. If in the absence of contrary evidence, payments in and out are considered to be simultaneous, then there will be a pari passu result. Only if there is contrary evidence will this presumption be displaced, and the sensible solution would therefore seem to be simply to place the burden of proof on the party claiming that the transactions occurred in a particular order.

The problem in Barlow Clowes is different, because in principle, it would have been possible to apply either of the other two tests. It would, however, have been expensive, and indeed the cost might have been so great as seriously to dissipate what remained in the fund. This will not always be the case in the silicon age, as Mr.Justice Parker observed in the Ontario case:
"The application of the general equitable rules of tracing referred to supra is both logical and fair. In this age of computerized banking, it can hardly be argued that in most instances an application of such principles will cause much inconvenience, difficulty or complication. These same principles are often applied to quite complicated dealings which do not involve bank accounts." ${ }^{\prime 31}$

The general rules of tracing to which he was referring were, in effect, the North American Rolling Charge.$^{32}$ This case is over a decade old, and it is reasonable to suppose that computerised banking has made the necessary calculations easier in the meantime. However, it is accepted that there may still be some cases, such as Barlow Clowes, where the number of transactions is very large, where expense may still be a major issue.

It has already been suggested that on other grounds, pari passu distribution was the most appropriate solution in Barlow Clowes, but if there had been no intention to form a common fund, it is felt that the expense arguments would not have justified departure from the North American Rolling Charge. In the first place, there is the problem of deciding at what stage the departure should be made, especially given that such departure might affect already-established rights. It is suggested, however, that there is no need to invoke a special rule to

3151 O.R. (2d) 212 at 239-240, quoted in (1986) 55 O.R. (2d) 673 at 679 h (Ont.C.A.).

${ }^{32}$ Although the expression "North American Rolling Charge" is never actually used in the case. 


\section{IN DEFENCE OF THE NORTH AMERICAN ROLLING CHARGE}

deal with this situation. If the cost of applying a particular method of distribution becomes so great as to dissipate a large part of the fund, it is clearly in the interests of all the parties to agree to some simpler form of settlement. In principle, this is no different from any other kind of litigation over limited funds. If one party can still see a clear gain from the application of the North American Rolling Charge, then it is for that party to bring the case, with the attendant litigation risks and costs.

There are, in any case, problems with basing a legal rule on the comparative costs of distribution methods, since especially in the age of computerised banking, these comparative costs can alter. It would be absurd to set in stone a particular distribution method, on the basis of comparative costs, when these could quickly go out of date. It is even possible to envisage situations where the difficulty and/or expense increases or decreases during the proceedings, perhaps because a cheaper method is developed of getting data into electronic form, or the only witness of fact dies, or records are destroyed. It would be absurd to alter the distribution method, thereby affecting established property rights. Once it is accepted that this cost is, in principle, no different from any other litigation cost, then these problems disappear.

\section{AUTHORITY}

Argument has been made so far for the general adoption of the North American Rolling Charge except in cases where it would be inappropriate, for example, where the parties are contributing to a common fund. If the applicability of Clayton's case is resolved in the House of Lords, as Lord Justice Woolf suggested in Barlow Clowes, ${ }^{33}$ then previous authority would not impede the development of the law, but in the meantime it is necessary to examine the authorities against the proposition for which argument is made. Despite Lord Justice Dillon's view in Barlow Clowes that there was clear authority against the adoption of the North American Rolling Charge, ${ }^{34}$ it is suggested that such authority as there is unconvincing.

There are a number of authorities for a pari passu method of distribution, but none of these is conclusive against the North American Rolling Charge, because either individual tracing issues were not decided, or the result would

${ }^{33}$ Supra.n.3.

${ }^{34}$ Supra.n.9. 


\section{DENNING LAW JOURNAL}

have been the same even if the North American Rolling Charge method had been used, or the case falls within one of the exceptions for which we have already argued. In Sinclair v. Brougham, the House of Lords held that a fund consisting a building society and ultra vires banking investments be held on a pari passu basis, and there is no doubt that a North American Rolling Charge basis of distribution would have led to a different result, except in the unlikely event that all investments were made simultaneously. However, it has already been suggested that at least for the building society shares, a pari passu distribution was probably justified as a common investment, and this may also vindicate its use in the distribution of the ultra vires banking investments. In any case, however, the House seemed concerned only to ascertain the respective distributions as between the two classes of investor, rather than determine individual entitlements, since the order was made subject to any individual tracing claim that may have been made. ${ }^{35}$ Sinclair is therefore not authority against the applicability in English law of the North American Rolling Charge.

There was also a pari passu distribution in Re Diplock, except for the running bank accounts, but Diplock also is not a strong authority against the North American Rolling Charge, because there was only one Diplock investment into each fund, and therefore the result would have been the same had the North American Rolling Charge method been adopted: In Barlow Clowes, pari passu was used, and the North American Rolling Charge method was considered too difficult to apply, but the ratio of the case is probably confined to common investment funds. ${ }^{36}$ Certainly, Lord Justice Dillon would not have applied pari passu except to a common investment, but it is also worth observing that none of the parties advanced a North American Rolling Charge argument. The debate was therefore confined to the relative merits of pari passu against Clayton's case, and the opportunity to consider serious arguments for the North American Rolling Charge did not arise. ${ }^{37}$

It is contended that Clayton's case ought never to be applicable to the resolution of competing equitable property interests. Clayton's case itself concerned the allocation of legal choses in action to amounts of money in a

${ }^{35}$ On this point alone the case was overruled in Westdeutsche supra.n.7.

${ }^{36}$ Supra.n. 19.

${ }^{37}$ Dillon L.J. also thought that the North American Rolling Charge was ruled out on the grounds of authority, and in particular the cases discussed in the following paragraph: supra.n.9. 


\section{IN DEFENCE OF THE NORTH AMERICAN ROLLING CHARGE}

bank account. The dispute was between banker and customer, and in this particular context, as a rule of convenience based on implied intention it was probably justified. McConville has argued strongly that there is no justification for applying Clayton's case beyond that context, ${ }^{38}$ but in Pennell $v$. Deffell, ${ }^{39}$ the principles from the case were extended to the distribution of competing proprietary claims to money in a bank account. The case is a weak authority, however, because as between beneficiaries and trustee the case was overruled in Re Hallett's Estate, ${ }^{40}$ and as between the beneficiaries themselves there was enough to go around anyway. In Re Diplock, Clayton's case was used, as part of the ratio, in respect of the Dr. Barnardo and National Institute for the Deaf funds, but unenthusiastically, since the main purport of Re Diplock is to apply pari passu where the equities are equal. ${ }^{41}$ Clayton's case was applied only to running bank accounts, as a rule of convenience, and was said to be based on implied intention, which of course is rebuttable. It is also unlikely that anybody had even thought of the concept of the North American Rolling Charge by the time of the decision, let alone of applying it. It is argued, therefore, that the authority is not strong, but it was used by Lord Justice Dillon in Barlow Clowes as Court of Appeal authority for the rejection of the North American Rolling Charge. It is difficult, however, to justify Clayton's case on the basis of implied intention in Re Diplock, since the next-of-kin and the charity had never had any contact with each other; indeed, the charity was unaware of the existence of the next-of-kin. Clearly, therefore, there was no common intention, and since the next-of-kin was unaware of the destination of the money, their intention cannot have been relevant. The only intention therefore which can be relevant is that of the charity, the volunteer who does the mixing, and it is suggested that to found a principle on the basis of the intention of the volunteer recipient is absurd.

It can be concluded that there is no convincing authority against the development of the North American Rolling Charge, but that in so far that it is ruled out by any statements made in Re Diplock, those statements should be regarded as wrong. In Barlow Clowes, only Lord Justice Dillon perceived that the North American Rolling Charge had been ruled out by authority; Lord

${ }^{38}$ D.A. McConville, "Tracing and the Rule in Clayton's Case" (1963) 79 L.Q.R. 388.

${ }^{39}$ (1853) 4 De G.M. \& G. 372, 43 E.R. 551

${ }^{40}$ Supra.n.5.

${ }^{41}$ Supra.n. $7 \&$ text, \& n. 17 \& text. 


\section{DENNING LAW JOURNAL}

Justices Woolf and Leggatt would both have been prepared to apply it had they considered it appropriate in the circumstances.

It is suggested, therefore, that even in the absence of a decision of the House of Lords reconsidering Clayton's case, the courts could adopt the principles which have been argued for in this article. 